\title{
The relationship between the soil water storage and water-use efficiency of seven energy crops
}

\author{
S. PODLASKI", S. PIETKIEWICZ ${ }^{*+}$, D. CHOŁUJ ${ }^{*}$, T. HORACZEK ${ }^{* *}$, G. WIŚNIEWSKI*, \\ D. GOZDOWSKI ${ }^{* * *}$, and H.M. KALAJI ${ }^{*}+$
}

Department of Plant Physiology, Faculty of Agriculture and Biology, Warsaw University of Life Sciences WULS-SGGW, 02-787 Warsaw, Nowoursynowska 166 St., Poland*

Department of Plant Production Engineering, Mazowian Reseach Center in Kłudzienko, Institute Technology and Life Sciences - ITP, Kłudzienko St. 7, 05-825 Grodzisk Mazowiecki, Poland**

Department of Experimental Design and Bioinformatics, Faculty of Agriculture and Biology, Warsaw University of Life Sciences WULS-SGGW, 02-787 Warsaw, Nowoursynowska 166 St., Poland***

\begin{abstract}
The aim of this work was to determine two types of photosynthetic water-use efficiency in order to examine their utility as selection criteria for tolerance of energy crops to soil water deficit. Furthermore, effects of crop cultivation on soil water content and storage were investigated. Seven energy crops were examined: miscanthus, prairie cordgrass, willow, thornfree rose, Virginia mallow, Bohemian knotweed, and topinambour. The highest values of instantaneous (WUE) and intrinsic $\left(\mathrm{WUE}_{\mathrm{i}}\right)$ water-use efficiencies were found for miscanthus and prairie cordgrass. The reduction of WUE and/or $\mathrm{WUE}_{\mathrm{i}}$ was caused mainly by a rapid rise in the transpiration rate and a greater stomatal conductance, respectively. Principal component analysis showed that neither WUE nor WUE $\mathrm{W}_{\mathrm{i}}$ could be recommended as universal selection criteria for the drought tolerance in different energy crops. The proper localization of soil with a good supply of water is most the important condition for energy crop plantations.
\end{abstract}

Additional key words: drought; gas exchange, selection criteria; soil water content.

\section{Introduction}

The environmental impact of growing energy crops, and particularly its effect on soil water content has not been well studied. Energy crops require large amount of water for their growth and vegetative biomass production. Deeprooted energy crops grown in soils with a large water availability were found to cause substantial reduction in the amount of ground water recharge below the root zone (Blanco-Canqui 2009).

The yield produced per unit of water consumed is referred to as the water-use efficiency (WUE). WUE may be estimated from a leaf and plant to crop scale. At the leaf scale, the instantaneous WUE represents the ratio of the instantaneous net $\mathrm{CO}_{2}$ assimilation rate $\left(P_{\mathrm{N}}\right)$ to transpiration $(E)$. This is also called the instantaneous photosynthetic WUE (Bacon 2004, Long 2003). The most generally useful value of WUE is the intrinsic photosynthetic water-use efficiency $\left(\mathrm{WUE}_{\mathrm{i}}\right)$, described as the ratio of the instantaneous net $\mathrm{CO}_{2}$ assimilation rate $\left(P_{\mathrm{N}}\right)$ to stomatal conductance $\left(g_{\mathrm{s}}\right)$ (Bacon 2004). Instantaneous WUE is particularly useful when comparing different plant genotypes of one plant species or when attempting to improve the efficiency of water use (Clifton-Brown et al. 2001). Attempts to increase water-use efficiency in plants have resulted in few successes (Tambussi et al. 2007, Fan et al. 2015).

Received 11 January 2016, accepted 6 January 2017, published as online-first 8 February 2017.

${ }^{+}$Corresponding authors; e-mail: stefan_pietkiewicz@sggw.pl, hazem@,kalaji.pl

Abbreviations: Ap, Bt, C - soil diagnostic horizons (based on FAO classification); CV - coefficient of variation; $\mathrm{C}_{4} \mathrm{G}-\mathrm{C}_{4}$ grasses; DM - dry mass; $E$ - transpiration rate; $g_{\mathrm{s}}$ - stomatal conductance; HPP - herbaceous perennial plants; LAI - leaf area index; NADP-ME - malate dehydrogenase (oxaloacetate-decarboxylating); PCA - principal component analysis; PEPCK - phosphoenolpyruvate carboxykinase; $P_{\mathrm{N}}$ - net photosynthetic rate; SRC - short-rotation coppices; WUE - instantaneous water-use efficiency; $\mathrm{WUE}_{\mathrm{i}}$ - intrinsic water-use efficiency; $\Phi$ - diameter.

Acknowledgements: We thank the Ministry of Science and Higher Education of The Republic of Poland for financing our research in the form of scientific grant No. N N310 308734 'Agricultural productivity and energy and emission value of biomass of energy crops grown under differentiated soil moisture conditions'.

(C) The Author(s). This article is published with open access at link.springer.com 
The main aims of this study were to examine the utility of instantaneous (WUE) and intrinsic $\left(W^{2} E_{i}\right)$ water-use efficiencies as selection criteria for tolerance of energy crops to water deficit, and to evaluate the effect of energy

\section{Material and methods}

Experimental conditions: A single-factor field experiment with seven rainfed energy crops in randomized blocks with three replicates was performed during the period of 2008-2010 on plantation, which was established in 2005 at the Skierniewice Experimental Station of WULS $\left(51^{\circ} 57^{\prime} \mathrm{N} 20^{\circ} 9^{\prime} \mathrm{E}\right)$. The harvested area of each plot was $150 \mathrm{~m}^{2}$. The soil at Skierniewice is a stagnic luvisol (FAO 2015) with the following fractions in the $0-25 \mathrm{~cm}$ soil layer: $>0.05 \mathrm{~mm} 87 \%, 0.002-0.05 \mathrm{~mm} 5 \%$, and $<0.002 \mathrm{~mm} \mathrm{7 \%}$ (Sosulski et al. 2015). It is characterized by a clay content $(\Phi<0.002 \mathrm{~mm})$ of $7-8 \%$ in the FAO classified horizons (FAO 2015) Ap (0-25), 4-5\% in the Bt (25-45), and $13-15 \%$ in the $\mathrm{Bt}$ and $\mathrm{C}$ horizons $(>45 \mathrm{~cm})$.

Weather conditions: In the years 1955-2005, the average annual rainfall in Skierniewice was $480-532 \mathrm{~mm}$ with a mean of $516 \mathrm{~mm}$. During the vegetation period (between April and September), the values were $226-470 \mathrm{~mm}$, with a mean of $342 \mathrm{~mm}$, respectively. In our study, for three consecutive seasons, the total rainfall recorded during vegetation was 292, 347, and $437 \mathrm{~mm}$. In June and July 2008, the rainfall was $65 \mathrm{~mm}$, which resulted in evident drought symptoms in plants. In following year, rainfall distribution was optimal for vegetation. Between May and September 2009, as well as during 2010, monthly rainfalls followed a more regular pattern, ranging from 82 to 155 mm (Fig. 1).

The average monthly air temperatures were 9.9, 8.7, and $7.6^{\circ} \mathrm{C}$ in 2008,2009 , and 2010 , respectively. Thus, 2008 may be considered 'dry', 2009 'average', and 2010 'humid' year.

Plant material: The species studied in this work belong to three groups recommended for use under European environmental conditions (El Bassam 1998, 2010). A set of seven energy crops was examined: miscanthus (Miscanthus $\times$ giganteus Anders.) and prairie cordgrass (Spartina pectinata Bosc. ex Link.) as tall $\mathrm{C}_{4}$ grasses $\left(\mathrm{C}_{4} \mathrm{G}\right.$ plants), willow (Salix vinimalis L., cv. Sprint) and rose (Rosa multiflora Thunb. cv. Jadar) as woody short-rotation coppices (SRC), and Virginia mallow (Sida hermaphrodita L. Rusby), Bohemian knotweed (Reynoutria $\times$ bohemica Chrtek \& Chrtkova), and topinambour (Jerusalem artichoke, Helianthus tuberosus L., cv. Albik) as dicotyledonous $\mathrm{C}_{3}$ herbaceous perennial plants (HPP).

Miscanthus belongs to subtype of malate dehydrogenase (oxaloacetate-decarboxylating, NADP-ME), and prairie cordgrass to a subtype of phosphoenolpyruvate carboxykinase (PEPCK); both are of $\mathrm{C}_{4}$ photosynthesis (Buchmann et al. 1996). Perennial grasses display many crop cultivation on soil water content and storage. Such data could enable a future design of principles for the sustainable and economically feasible production of energy crop biomass.

beneficial attributes as energy crops, and there has been increasing interest in their use in the U.S. and Europe since the middle of eighties of the last

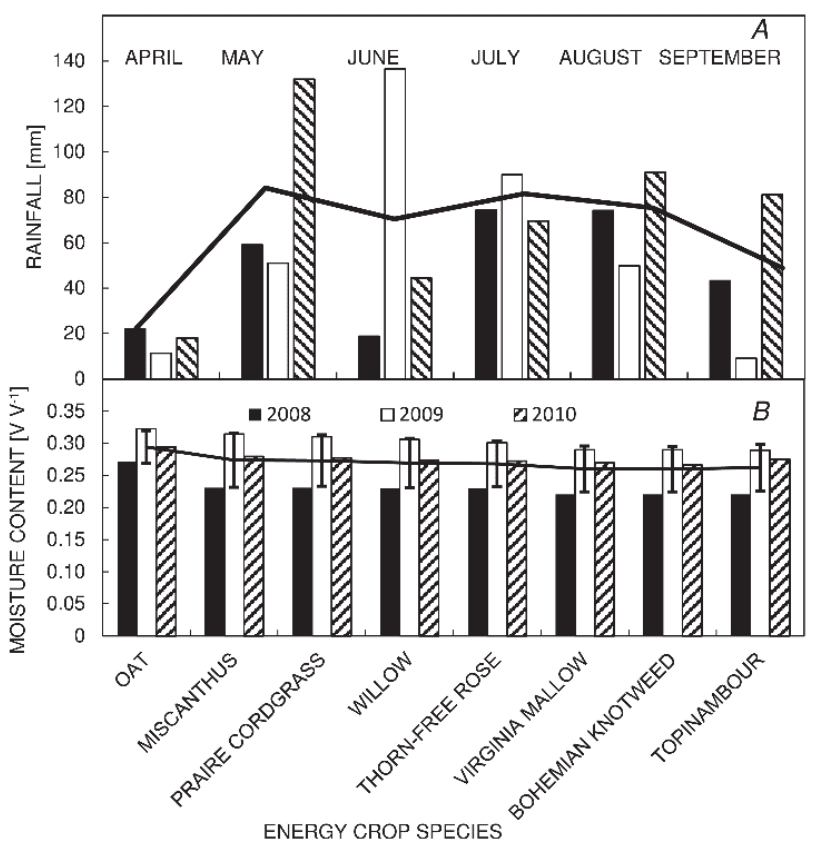

Fig. 1. Monthly precipitation (vertical bars) and three years mean (line) in the study site between 2008 and $2010(A)$. Average soil moisture content $\left(\mathrm{v} \mathrm{v}^{-1}\right)$ under control (oat) and seven individual energy crops between 2008 and $2010(B)$. The bars show data for each year, line is the three years mean.

century (Lewandowski et al. 2003). Miscanthus is a triploid synthetic hybrid of Miscanthus sinensis and M. sacchariflorus, high productive $\mathrm{C}_{4}$ grass. It can be cultivated in many sites within a temperate climate. Harvested biomass contains a high amount of dry matter. Plants are resistant to seasonal droughts, but susceptible to frosts below $-10^{\circ} \mathrm{C}$. High productive $\mathrm{C}_{4}$ grass, prairie cordgrass, grows in the natural environment. The species can be cultivated on V and VI soil class. It shows some frost resistance and can be easily cultivated under Polish climatic conditions (El Bassam 2010).

Willow (cv. Sprint) and thorn-free rose (cv. Jadar) are woody short-rotation coppices (SRC). Willow is a very popular species among North European flora. The yield of SRC willow biomass under Polish climatic conditions is 10-15 $\mathrm{t}$ (dry mass, DM) ha ${ }^{-1}$. This energy crop has very high water and fertilizer requirements, its plantation is very difficult to be maintained, and a specialized equipment is necessary at time of harvest. Thorn-free rose is also very 
popular among Polish flora. It is broadly tolerant to the $\mathrm{pH}$ upon which is cultivated, and has low soil requirements. Harvesting its biomass is very troublesome and is done only using hand cutters (El Bassam 2010).

Bohemian knotweed (Reynoutria $\times$ bohemica Chrtek \& Chrtkova), Virginia mallow (Sida hermaphrodita L. cv. Rusby), and topinambour (Jerusalem artichoke, H. tuberosus L.) are dicotyledonous $\mathrm{C}_{3}$ herbaceous perennial plants (HPP). Reynoutria $\times$ bohemica, a natural hybrid of Fallopia japonica Houtt and F. sachalinensis (F.W. Schmidt ex Maxim) is a very invasive plant growing in the vicinity of rivers. Fresh leaves and biomass contain many allelochemicals that can be used as natural fungicides. Virginia mallow is highly productive HPP, resistant to drought due to its huge rhizosphere. It can be cultivated on soils having a low water table level. Its dried biomass can be sued as raw material for producing briquettes and pellets. The aboveground biomass of Jerusalem artichoke can be used for the production of different forms of bioenergy (biogas, briquettes, and pellets), while its tubers can be used for production of bioethanol. In addition, it may be exploited as a dietetic food for people with overly acidic stomachs, or by diabetics as a good source of energy (El Bassam 2010).

The choice of all these crops was based on their cultivation efficiency under Central European conditions. The recommended plant density was: miscanthus 10.000 , willow -32.000 , Virginia mallow -16.000 , rose - 16.000, topinambour -25.000 , Bohemian knotweed 16.000, and prairie cordgrass -25.000 [plants ha ${ }^{-1}$ ]. The plant density resulted in the maximum LAI values $\left(\mathrm{m}^{2} \mathrm{~m}^{-2}\right)$, usually reached by the end of June/beginning of July (Table 1S, supplement available online). The biggest variability in maximum LAI across 3-year investigation displayed miscanthus $[6.38 \pm 1.06$, coefficient of variation (CV) of $16.6 \%]$ and prairie cordgrass $(6.77 \pm 0,90, \mathrm{CV}$ of $13.3 \%)$, while the lowest one were found for thorn-free rose $(4.89 \pm 0.21, \mathrm{CV}$ of $4.3 \%)$, Bohemian knotweed $(8.46$ $\pm 0.41, \mathrm{CV}$ of $4.8 \%)$, and willow $(6.37 \pm 0.34, \mathrm{CV}$ of $5.3 \%$ ). The biggest LAI of Bohemian knotweed, on average $8.46 \mathrm{~m}^{2} \mathrm{~m}^{-2}$, showed a rather small variability within the years of investigation.

Parameters measured: Each year, at the beginning of measurement period (June), in the middle (July), and at the end (August), ten fully developed representative leaves were taken at random, for measuring photosynthetic rate $\left(P_{\mathrm{N}}\right)$, transpiration rate $(E)$, and stomatal conductance $\left(g_{\mathrm{s}}\right)$. These parameters were assessed using $L I-6400$ portable photosynthesis system ( $L i$-cor Ltd., Lincoln, NE, USA).

\section{Results}

Water-use efficiencies of energy crops: Instantaneous WUE depended on atmospheric rainfall and species. Over the three years of the study, SRC willow and thorn-free rose showed the lowest values, i.e. 3.02 and $4.36 \mathrm{~mol}\left(\mathrm{CO}_{2}\right)$
The gas-exchange parameters were measured under relatively stable environmental conditions from 7:00-11:00 $\mathrm{h}$ local time, with natural irradiances of average intensity of $1,350 \mu \mathrm{mol}$ (photon) $\mathrm{m}^{-2} \mathrm{~s}^{-1}$, temperatures of $23-30^{\circ} \mathrm{C}$, and $\mathrm{CO}_{2}$ concentrations of $350-400 \mu \mathrm{mol} \mathrm{mol}{ }^{-1}$ (air). Both WUE $\left(P_{\mathrm{N}} / E\right)$ and $\mathrm{WUE}_{\mathrm{i}}\left(P_{\mathrm{N}} / g_{\mathrm{s}}\right)$ were calculated based on $P_{\mathrm{N}}, E$, and $g_{\mathrm{s}}$ values. Each year (in March) the yield of DM of the aboveground parts of the plants was determined in ten replications after grounding fragmentation.

Soil moisture content and storage: To assess soil moisture and its water deficit, a PR Profile Probe (Delta$T$ Devices Ltd., Cambridge, UK) was used. The probes used (five per plot) in the experiment were calibrated using standards prepared for mineral soils. This made possible to calculate the water storage in soil layers of $0-10,10-20$, $20-30,30-40,40-60$, and $60-100 \mathrm{~cm}$. Soil water storage was calculated for each depth of a soil profile, using the following formula:

Storage $[\mathrm{mm}]=10 \times \mathrm{M} \times \mathrm{h}($ Biniak-Pieróg et al. 2014)

where $\mathrm{M}$ represents soil moisture content $\left(\mathrm{m}^{2} \mathrm{~m}^{-2}\right)$ and $\mathrm{h}$ represents the thickness (in $\mathrm{cm}$ ) of the soil profile. Soil water storage was the sum of water storage for each soil level to a depth of $1 \mathrm{~m}$. All measurements were taken at weekly time intervals, beginning in April.

A traditional cereal crop, oat (hulled morphotype of the oat (Avena sativa L, cv. Sam, Strzelce Plant Breeding Co., average annual yield of $4.1 \mathrm{tha}^{-1}$ and plant density of 460 plants $\mathrm{m}^{-2}$ ) was used as the control in order to compare the effect of energy crop cultivation on these soil moisture parameters.

Statistical analysis: Obtained data were examined by analysis of the variance (ANOVA) and the Tukey's test $(P<0.05)$ was used to compare the means (Statgraphics version 4.w 3.1). Analysis of correlation and regression (Sokal and Rohlf 1995) as well as principal component analysis (PCA, Jolliffe 2002) were used for evaluating the relationship between the pairs of traits. PCA was applied for the average values of the traits for all years under study. A PCA scatter plot described the relationship between all traits, showing which traits were positively (similar value of PC1 and PC2), negatively, and did not correlate at all (perpendicular lines for the traits). On the basis of the scatter plot presenting seven energy crops and according to all traits examined, it was possible to evaluate those crops that were similar and those of either high or low values of measured parameters.

$\mathrm{mol}^{-1}\left(\mathrm{H}_{2} \mathrm{O}\right)$, respectively (Table 1$)$. Following an increase in rainfall (in 2008: 292, 2009: 347, and 2010: $437 \mathrm{~mm}$ ), a decrease in WUE was found both in $\mathrm{C}_{4} \mathrm{G}$ and SRC plants. This was mainly a result of the increased $E$ : in 2008: 3.04, 
2009: 3.92, and 2010: 8.96 for $\mathrm{C}_{4} \mathrm{G}$, and 2.21, 4.48, and $13.99 \mathrm{mmol}\left(\mathrm{H}_{2} \mathrm{O}\right) \mathrm{m}^{-2} \mathrm{~s}^{-1}$ for $\mathrm{SRC}$, respectively (Podlaski et al., data not published), depending on $g_{\mathrm{s}}$. This was particularly evident in SRC, which displayed water economy characterized by a high water loss in 2010. Quite the opposite trend was found in HPP, where the differences between the WUE of these crops in 2008 and 2010 were often insignificant.

The highest $\mathrm{WUE}_{\mathrm{i}}$ values usually occurred in the dry part of 2008 as a result of decreased $g_{\text {s }}$ (Table 1). In general, an increase in rainfall produced greater $g_{\mathrm{s}}$ [averages for seven energy crops in 2008, 2009, and 2010 were 149,235 , and $572 \mathrm{mmol}\left(\mathrm{H}_{2} \mathrm{O}\right) \mathrm{m}^{-2} \mathrm{~s}^{-1}$, respectively] (Podlaski et al., data not published), which resulted in a lowered $\mathrm{WUE}_{\mathrm{i}}$. The variations between groups of plants were large and significant.

The WUE and $\mathrm{WUE}_{\mathrm{i}}$ of both photosynthesis subtypes of $\mathrm{C}_{4}$-energy crops, NADP-ME and PEPCK, differed depending on the weather conditions. Miscanthus saved more water than prairie cordgrass during the dry vegetation season, while during an average season, the latter one performed better. This was due to the substantial differences in $g_{\mathrm{s}}$ and $E$ response to actual weather conditions.

\section{Effect of energy crop cultivation on soil water content:} The average soil moisture content for all layers $(0-100 \mathrm{~cm})$ of the soil profile in 2008, 2009, and 2010 differed significantly, with values of $0.242,0.314$, and $0.283 \mathrm{~m}^{3} \mathrm{~m}^{-3}$, respectively (data not shown). On the average for three years of the study, the moisture content of the soil under the energy crops, for all layers of the soil profile, was significantly lower by $0.030 \mathrm{~m}^{3} \mathrm{~m}^{-3}$, when compared with the soil under the control oat monoculture (Table 2).

Growing individual energy crops had quite different effects on soil moisture. Topinambour, Bohemian knotweed, Virginia mallow, and thorn-free rose significantly lowered the moisture of soil beneath them by 0.035 , $0.050,0.037$, and $0.031 \mathrm{~m}^{3} \mathrm{~m}^{-3}$, respectively, when compared with the oat control (Fig. 1).

The cultivation of all energy crops lowered soil moisture. The lowest insignificant reduction occurred in $\mathrm{C}_{4} \mathrm{G}$ crops. On average, the culture of $\mathrm{C}_{4} \mathrm{G}$ plants lowered soil moisture by $0.023 \mathrm{~m}^{3} \mathrm{~m}^{-3}$, which was insignificantly different from the control. The cultivation of various energy crops was found to affect the soil moisture at various soil profile depths quite differently. Cultivating $\mathrm{C}_{4} \mathrm{G}$ crops significantly lowered soil moisture, starting from the depth of $60-100 \mathrm{~cm}$, whereas in HPP the reduction of soil moisture appeared at $30-40 \mathrm{~cm}$ depth. Differences in the moisture content of the soil under the energy crops and under the control oat monoculture, increased with the soil profile depth. The significant differences between these two parameters already appeared at the $30-40 \mathrm{~cm}$ depth (Table 2).

Changes in soil moisture, due to the variable atmospheric rainfall and the cultivation of energy crops, affected soil water storage during the vegetation period (April-September). Soil water storage at a depth of $1 \mathrm{~m}$, being the sum of water storage for all soil levels, was significantly the highest in 2009 (335.4 mm), in the middle of 2010 (326.7 mm), and the lowest in 2008 (294.1 mm). Soil water storage was significantly lower beneath HPP and $\mathrm{SRC}$ and higher under $\mathrm{C}_{4} \mathrm{G}$ plants when compared with the soil water storage under oat (Table 3 ).

On average, for the three years of the study, the moisture storage of the soil beneath the energy crops was lower by 23.8 to $44.1 \mathrm{~mm}$, depending on the species, when compared with the control soil under oat. The significantly lower water storage was in the soil of SRC Virginia mallow and Bohemian knotweed (Table 3).

Table 1. Instantaneous (WUE) and intrinsic $\left(\mathrm{WUE}_{\mathrm{i}}\right)$ water-use efficiencies of seven energy crops in the period of 2008-2010. The results represent the means, where $n=30 . \mathrm{C}_{4} \mathrm{G}-\mathrm{C}_{4}$ grasses; SRC - short-rotation coppice; HPP - herbaceous perennial plants; $\mathrm{M}$ - miscanthus; $\mathrm{C}$ - prairie cordgrass; $\mathrm{W}$ - willow; $\mathrm{R}$ - rose; Vm - Virginia mallow; Bk - Bohemian knotweed; $\mathrm{T}$ - topinambour. Different capital and small letters denote the difference at $P<0.05$ in the rows and columns, respectively.

\begin{tabular}{|c|c|c|c|c|c|c|c|c|}
\hline \multirow[t]{2}{*}{ Year } & \multicolumn{2}{|l|}{$\mathrm{C}_{4} \mathrm{G}$} & \multicolumn{2}{|l|}{$\mathrm{SRC}$} & \multicolumn{3}{|l|}{ HPP } & \multirow[t]{2}{*}{ Mean } \\
\hline & M & $\mathrm{C}$ & $\mathrm{W}$ & $\mathrm{R}$ & $\mathrm{Vm}$ & $\mathrm{Bk}$ & $\mathrm{T}$ & \\
\hline \multicolumn{9}{|c|}{ WUE $\left[\mathrm{mol}\left(\mathrm{CO}_{2}\right) \mathrm{mol}^{-1}\left(\mathrm{H}_{2} \mathrm{O}\right)\right]$} \\
\hline 2008 & 7.67 & 5.47 & 4.65 & 6.24 & 4.18 & 4.85 & 3.89 & $5.28^{\mathrm{b}}$ \\
\hline 2009 & 5.56 & 7.60 & 3.28 & 5.15 & 8.51 & 7.43 & 8.00 & $6.50^{\mathrm{c}}$ \\
\hline 2010 & 2.68 & 2.62 & 1.14 & 1.70 & 3.00 & 3.44 & 3.30 & $2.55^{\mathrm{a}}$ \\
\hline Mean of year & $s 5.30^{c}$ & $5.23^{c}$ & $3.02^{\mathrm{a}}$ & $4.36^{\mathrm{b}}$ & $5.23^{\mathrm{c}}$ & $5.24^{\mathrm{c}}$ & $5.06^{\mathrm{c}}$ & \\
\hline $\begin{array}{l}\text { Average of } \\
\text { group }\end{array}$ & $5.27^{\mathrm{b}}$ & & $3.69^{\mathrm{a}}$ & & $5.18^{\mathrm{b}}$ & & & \\
\hline \multicolumn{9}{|c|}{$\mathrm{WUE}_{\mathrm{i}}\left[\mathrm{mol}\left(\mathrm{CO}_{2}\right) \mathrm{mol}^{-1}\left(\mathrm{H}_{2} \mathrm{O}\right)\right]$} \\
\hline 2008 & 245.3 & 189.0 & 169.7 & 205.5 & 69.7 & 87.8 & 49.4 & $145.2^{\mathrm{c}}$ \\
\hline 2009 & 162.3 & 232.9 & 107.3 & 91.3 & 75.4 & 97.9 & 64.8 & $118.8^{\mathrm{b}}$ \\
\hline 2010 & 43.1 & 56.1 & 19.2 & 41.8 & 45.0 & 37.7 & 23.2 & $38.0^{\mathrm{a}}$ \\
\hline Mean & $150.2^{\mathrm{d}}$ & $159.3^{\mathrm{d}}$ & $98.7^{\mathrm{c}}$ & $112.9^{c}$ & $63.4^{\mathrm{ab}}$ & $74.5^{\mathrm{b}}$ & $45.8^{\mathrm{a}}$ & \\
\hline Average & $154.8^{\mathrm{c}}$ & & $105.8^{\mathrm{b}}$ & & $61.2^{\mathrm{a}}$ & & & \\
\hline
\end{tabular}


Table 2. Comparison of moisture content $\left[\mathrm{m}^{3} \mathrm{~m}^{-3}\right]$ in soil under oat (control) and energy crops at different layers of soil profile. $\mathrm{C}_{4} \mathrm{G}$ refers to $\mathrm{C}_{4}$ grasses, SRC to short-rotation coppice, and HPP to herbaceous perennial plants. The results represent the means where $n=15$. Different small letters denote the difference at $P<0.05$.

\begin{tabular}{llllllll}
\hline \multirow{2}{*}{ Crop } & \multicolumn{3}{c}{ Depth of soil profile [cm] } & & \multicolumn{2}{c}{ Mean } \\
& $0-10$ & $10-20$ & $20-30$ & $30-40$ & $40-60$ & $60-100$ & \\
\hline Oat (control) & $0.143^{\mathrm{a}}$ & $0.224^{\mathrm{a}}$ & $0.252^{\mathrm{a}}$ & $0.304^{\mathrm{b}}$ & $0.396^{\mathrm{b}}$ & $0.444^{\mathrm{b}}$ & $0.294^{\mathrm{b}}$ \\
SRC & $0.129^{\mathrm{a}}$ & $0.205^{\mathrm{a}}$ & $0.227^{\mathrm{a}}$ & $0.268^{\mathrm{ab}}$ & $0.360^{\mathrm{ab}}$ & $0.400^{\mathrm{a}}$ & $0.264^{\mathrm{a}}$ \\
$\mathrm{HPP}$ & $0.112^{\mathrm{a}}$ & $0.201^{\mathrm{a}}$ & $0.221^{\mathrm{a}}$ & $0.264^{\mathrm{a}}$ & $0.339^{\mathrm{a}}$ & $0.390^{\mathrm{a}}$ & $0.255^{\mathrm{a}}$ \\
Mean & $0.125^{\mathrm{a}}$ & $0.212^{\mathrm{a}}$ & $0.225^{\mathrm{a}}$ & $0.273^{\mathrm{a}}$ & $0.355^{\mathrm{a}}$ & $0.396^{\mathrm{a}}$ & $0.264^{\mathrm{a}}$ \\
$\begin{array}{l}\text { Differences between oat and } \\
\text { means of energy crops }\end{array}$ & 0.018 & 0.012 & 0.027 & $0.031^{\mathrm{a}}$ & $0.041^{\mathrm{a}}$ & $0.048^{\mathrm{a}}$ & $0.030^{\mathrm{a}}$ \\
\hline
\end{tabular}

Table 3. Soil water storage $[\mathrm{mm}]$ at $0-100 \mathrm{~cm}$ of soil profile depth, in 2008-2010 beneath seven energy crops. $\mathrm{C}_{4} \mathrm{G}-\mathrm{C}_{4}$ grasses; $\mathrm{SRC}$ - short-rotation coppice; HPP - herbaceous perennial plants. The results represent the means of $n=5$. Different capital and small letters denote the difference at $P<0.05$ in the rows and columns, respectively.

\begin{tabular}{lllllll}
\hline Energy crop & \multirow{2}{*}{ Group of plants } & $\begin{array}{l}\text { Years } \\
\text { 2008 }\end{array}$ & 2009 & 2010 & \multicolumn{3}{l}{$\begin{array}{l}\text { Mean } \\
2008-2010\end{array}$} \\
\hline Oat & Control & 315.2 & 383.5 & 348.8 & 349.2 & $349.2^{\mathrm{b}}$ \\
Miscanthus & $\mathrm{C} 4 \mathrm{G}$ & 299.8 & 344.5 & 326.1 & $323.5^{\mathrm{ab}}$ & $27.4^{\mathrm{ab}}$ \\
Prairie cordgrass & & 299.8 & 343.0 & 351.3 & $325.4^{\mathrm{c}}$ & \\
Willow & SRC & 300.5 & 341.2 & 324.4 & $322.0^{\mathrm{ab}}$ & $323.4^{\mathrm{a}}$ \\
Thorn-free rose & & 296.8 & 331.1 & 346.3 & $324.7^{\mathrm{b}}$ & \\
Virginia mallow & HPP & 287.2 & 323.9 & 304.3 & $305.1^{\mathrm{a}}$ & $309.8^{\mathrm{a}}$ \\
Bohemian knotweed & & 280.3 & 330.7 & 320.2 & $310.4^{\mathrm{a}}$ & \\
Topinambour & & 294.2 & 333.6 & 314.1 & $314.9^{\mathrm{ab}}$ & \\
Mean & & $294.1^{\mathrm{a}}$ & $335.4^{\mathrm{b}}$ & $326.7^{\mathrm{b}}$ & & \\
\hline
\end{tabular}

A negative correlation between soil water storage and WUE was found for $\mathrm{C}_{4} \mathrm{G}$ and SRC plants, and when summing up all data of three years of the investigation (Fig. 2). Nevertheless, these relationships were weak, with a determination coefficient varying from 11.8 (total mean of three years) to $41.7 \%$ (mean for SRC). Such relationships can be explained by lowering WUE value with increased rainfalls in 2009 and 2010 which resulted in increasing soil water storage. Presented data suggest that mainly the rainfall determined soil water storage rather than evapotranspiration.

The reciprocal relationship occurred in HPP, the increased WUE also improved soil water storage. It was caused by quite different dynamics of WUE comparing with two other energy crop groups. The highest value of both WUE and soil water storage was in 2009, while in 2008 and 2010, the values of WUE were similar. A positive correlation $\left(R^{2}=0.7492\right)$ was found between the average soil water storage and the biomass yield of all crops over the 3 years of the study (Fig. 3). According to the regression equation, a $1-\mathrm{mm}$ increment in water storage in the range of 305-331.4 mm was accompanied by an increase in the biomass yield of $0.43 \mathrm{tha}^{-1}$.

Relationship between soil water storage and biomass yield for individual groups of energy crops was also positive, but much less, with determination coefficient varying from 6.9 to $18.1 \%$. Nevertheless, due to the similar trend in individual groups, a significant relationship between soil water storage and biomass yield was found after summing up all data for seven energy crop species and three years of investigation.

Utility of WUE and $W E_{i}$ as criteria for evaluating tolerance of energy crops to water shortage: Over the course of the whole study, the relationship between biomass yield and WUE or $\mathrm{WUE}_{\mathrm{i}}$ was positive in Bohemian knotweed and Virginia mallow; a significantly negative correlation was found only in miscanthus and prairie cordgrass (Table 4). The relationship between WUE and biomass yield was determined mainly by a dynamics of changes in the biomass yield in 2008 and 2009, because both WUE and $\mathrm{WUE}_{\mathrm{i}}$ decreased with the increasing rainfalls in consecutive years. In 2010, the biomass yield for $\mathrm{C}_{4} \mathrm{G}$ and Jerusalem artichoke increased as compared to 2008 from 9.7 to 16.9 and 7.5 to $14.3 \mathrm{tha}^{-1}$, respectively, while WUE lowered 1.5-2 or 1.2 times, respectively. The reduction in $\mathrm{WUE}_{\mathrm{i}}$ was bigger reaching 4.4 times lesser values for $\mathrm{C}_{4} \mathrm{G}$ and Jerusalem artichoke. As the consequence a negative correlation between the WUE and biomass yield and $\mathrm{WUE}_{\mathrm{i}}$ and biomass yield in these crops was found. In the case of SRC, in 2008 and 2010 , the changes in their biomass yield were small, while both WUE and WUE $_{\mathrm{i}}$ decreased. Thus, no significant correlation between $\mathrm{WUE}_{\mathrm{i}}$ and the biomass yield occurred. 


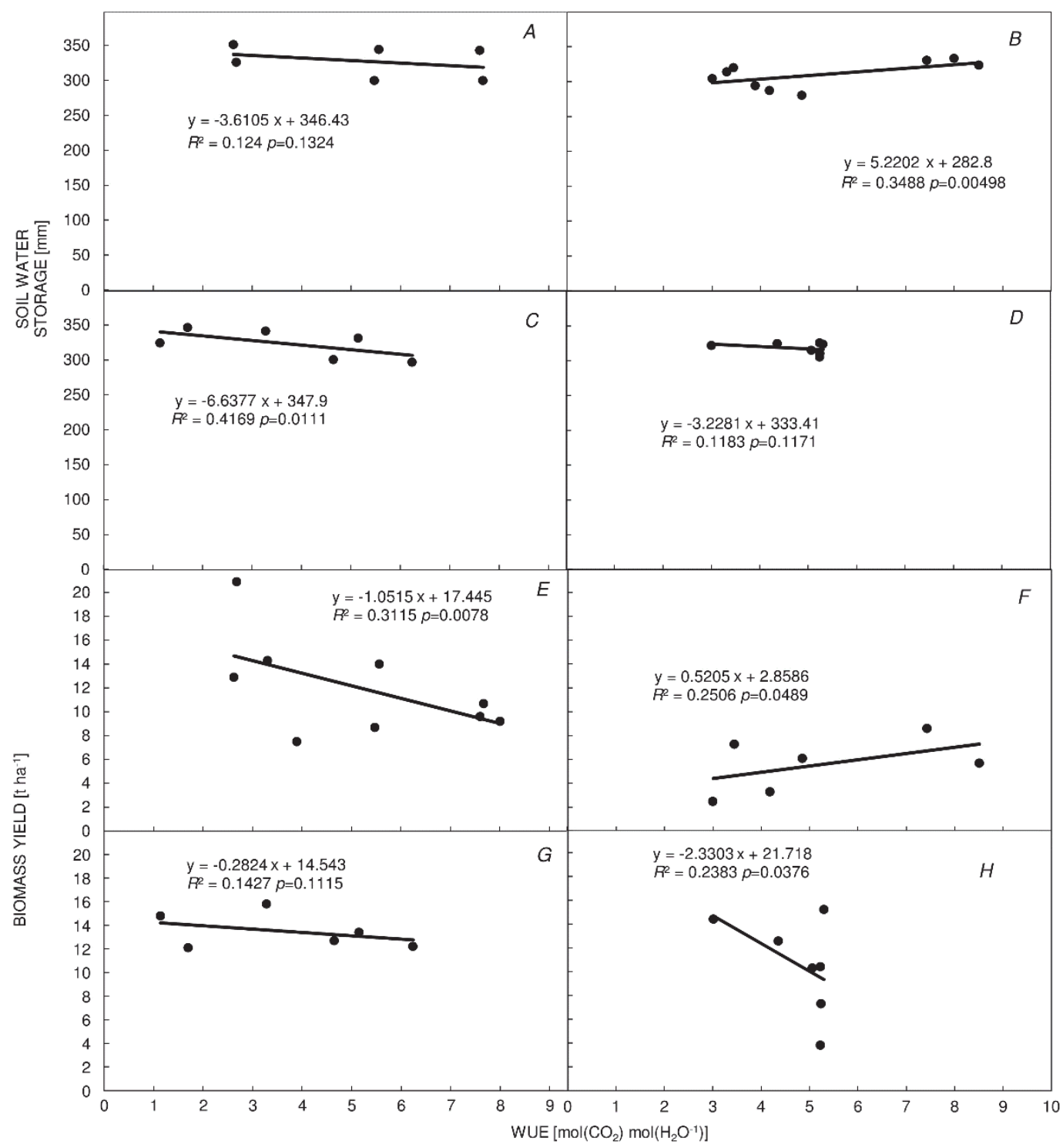

Fig. 2. Relationship between instantaneous water-use efficiency (WUE) and soil water storage $(A-D)$, and biomass yield $(E-H)$ in fieldgrown energy crops of three principal groups analyzed separately: tall $\mathrm{C}_{4}$ grasses $\left(\mathrm{C}_{4} \mathrm{G}\right)(A, E)$, short rotation coppices $(\mathrm{SRC})(C, G)$, high productive perennials (HPP) $(B, F)$, and all plant groups together $(D, H)$. Fitting equations, determination coefficients and $p$-value are given.

In Virginia mallow and Bohemian knotweed, the lowering in WUE and $\mathrm{WUE}_{\mathrm{i}}$ was accompanied with the declining yield. Therefore positive correlation between these parameters was found (Fig. 2).

Summing up, our data pointed out that various relationships between either WUE or $\mathrm{WUE}_{\mathrm{i}}$, and biomass yield resulted from an increase of the yield in $\mathrm{C}_{4} \mathrm{G}$ and a decrease of yield in HPP, together with an increase in rainfall that lowered these efficiencies. With calculation based upon all crop species used over three years of this study, the correlation coefficients between WUE or WUE $\mathrm{i}_{\mathrm{i}}$ and biomass yield were -0.488 and -0.049 , respectively.

A scatter diagram of PCA showing the principal components, i.e. PC1 (soil water availability) and PC2 (plant water use) (Fig. 4) demonstrated that these two components were sufficient to explain the greater part (about $81 \%$ ) of the variability observed within the recorded parameters through soil water availability and plant water use. Water storage and soil moisture content were readily identified, because both lines were parallel and almost closed against the line showing the biomass yield. This means that these traits were very positively correlated. Due to this, the PC1 can be named soil water availability. The PC2 component was named plant water use, determined mainly by $E$ and to a lesser extent by $g_{\mathrm{s}}$. Directions of lines for the other traits confirmed a weak correlations between $\mathrm{WUE}_{\mathrm{i}}, P_{\mathrm{N}}, E$, and the yield. No correlation between WUE, $g_{\mathrm{s}}$, and the yield was found (Fig. 4). 


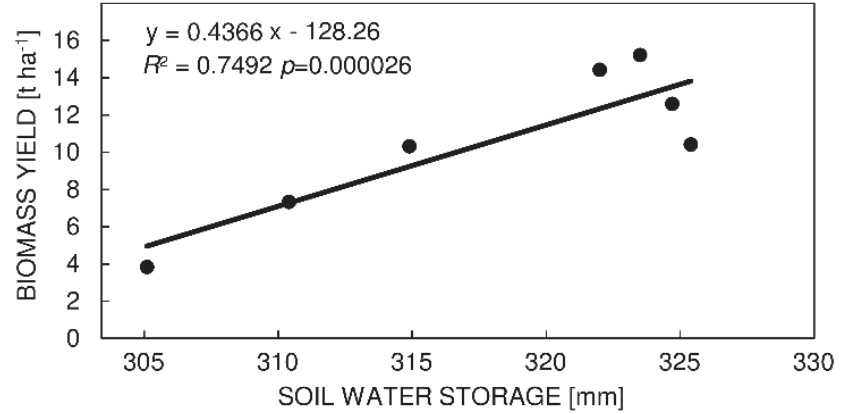

Fig. 3. Relationship between biomass yield and soil water storage of energy crops of the three principal studied groups: tall $\mathrm{C}_{4}$ grasses $\left(\mathrm{C}_{4} \mathrm{G}\right)$, short-rotation coppices (SRC), and high productive perennials (HPP) of three years of investigation. Fitting equations, determination coefficients and $p$-value were given.

From the coordinates (values of PC1 and PC2) for the particular crops (Fig. 4), it is possible to conclude that miscanthus and prairie cordgrass performed in a similar way according to the set of the physiological parameters analyzed and were characterized by high WUE and $P_{\mathrm{N}}$ values and low $g_{\mathrm{s}}$ values. Bohemian knotweed and Virginia mallow formed the next group, characterized by

\section{Discussion}

In order to interpret correctly the obtained WUE values, it is important to define which components of the ratio (numerator or denominator) exert a larger effect in causing the variability of this parameter. The $\mathrm{CV}$ of the $P_{\mathrm{N}}$ was $29.6 \%$, while for $E$ and $g_{\text {s }}$, the CV values were 69.9 and $75.9 \%$, respectively (Podlaski et al., data not published). This data clearly showed that water utilization should have a greater effect on both WUE and WUE than $P_{\mathrm{N}}$ itself. Also, Condon et al. (2002) and Blum (2005) indicated that genotypic differences in WUE are driven mainly by variations in water use rather than by variations in plant production or assimilation per amount of water used.

Blum (2005) observed that WUE can be associated with a higher yield in one type of environment, but may have no effect, or even be detrimental, in other environments. Similarly, in our study, we found the lack of a strict relationship between WUE and the biomass yield relative to various years of experiments and the different groups of energy crops. According to Blum (2009), greater genotypic transpiration efficiency (TE) and WUE are driven mainly by plant traits, which reduce transpiration and crop water use, processes that are crucially important for plant production. Nearly the same phenomenon occurred in our studies. The use of instantaneous WUE in the performance assessment of various crops is complicated due to the leaf $P_{\mathrm{N}}$, which is poorly correlated with the yield when the different genotypes of a crop species are compared (Long et al. 2006). This is a result of the increased $g_{\mathrm{s}}$ and $E$ in $\mathrm{C}_{4} \mathrm{G}$.
Table 4. Single correlation matrix between yield of biomass in seven energy crops and instantaneous (WUE) and intrinsic $\left(\mathrm{WUE}_{\mathrm{i}}\right)$ water-use efficiency. ${ }^{*}$ and ${ }^{* *}$ indicate significance at 5 and $1 \%$, respectively.

\begin{tabular}{lll}
\hline Energy crop & WUE & WUE $_{\mathrm{i}}$ \\
\hline Miscanthus & $-0.984^{* *}$ & $-0.982^{* *}$ \\
Prairie cordgrass & $-0.791^{*}$ & $-0.883^{* *}$ \\
Willow & 0.082 & 0.189 \\
Thorn-free Rose & 0.285 & 0.072 \\
Virginia mallow & $0.956^{*}$ & $0.815^{* *}$ \\
Bohemian knotweed & 0.613 & 0.265 \\
Topinambour & -0.353 & $-0.813^{* *}$ \\
\hline
\end{tabular}

low values for the majority of parameters, with the low yield, water storage, and soil water moisture. Willow and thorn-free rose were similar, when their physiological traits were assessed, yet they showed a high $E$. Topinambour differed from all of the other energy crops, from the perspective of its high $g_{s}$ along with its low values for the other traits. The location of topinambour in the center of the scatter plot indicates moderate values of most of the physiological traits examined for that crop (Sokal and Rohlf 1995).

Differences in the response of miscanthus and prairie cordgrass to differentiated sum and distribution of rainfall might reflect differences in the plant hydraulic architectures (Kocacinar and Sage 2003) and strategies for water utilization (Long 1999). They can also result from changes in their metabolism of subtype $\mathrm{C}_{4}$ photosynthesis (Ripley et al. 2010). The findings of our study confirmed those of Hall (2003) and Long et al. (2006), who warned that the cultivation of energy crops can adversely affect both the level of soil moisture and soil water storage, especially in the deeper layers. A clear reduction in moisture and soil water storage under cultures of HPP, together with its lowest $E$ among all studied energy crop groups, is associated with a high area of leaves (usually equal to a critical or above LAI, providing $95 \%$ absorption PAR by the canopy), the total transpiration of which causes increases in both the water uptake and the evaporation of soil water.

The importance of soil water status and plant water use for biomass production clearly speaks for the need to localize energy crop plantations on wet areas, but not in very near vicinity of rivers. Under such conditions both high atmospheric saturation and soil water availability would profitably affect the biomass yields of these crops.

Distributions of Bohemian knotweed plantations in areas, where moisture is available, should not provide any problems with the invasion of the species. Bohemian knotweed occurs only very seldom as a weed in agricultural areas (Balogh 2008). Furthermore, our observations 


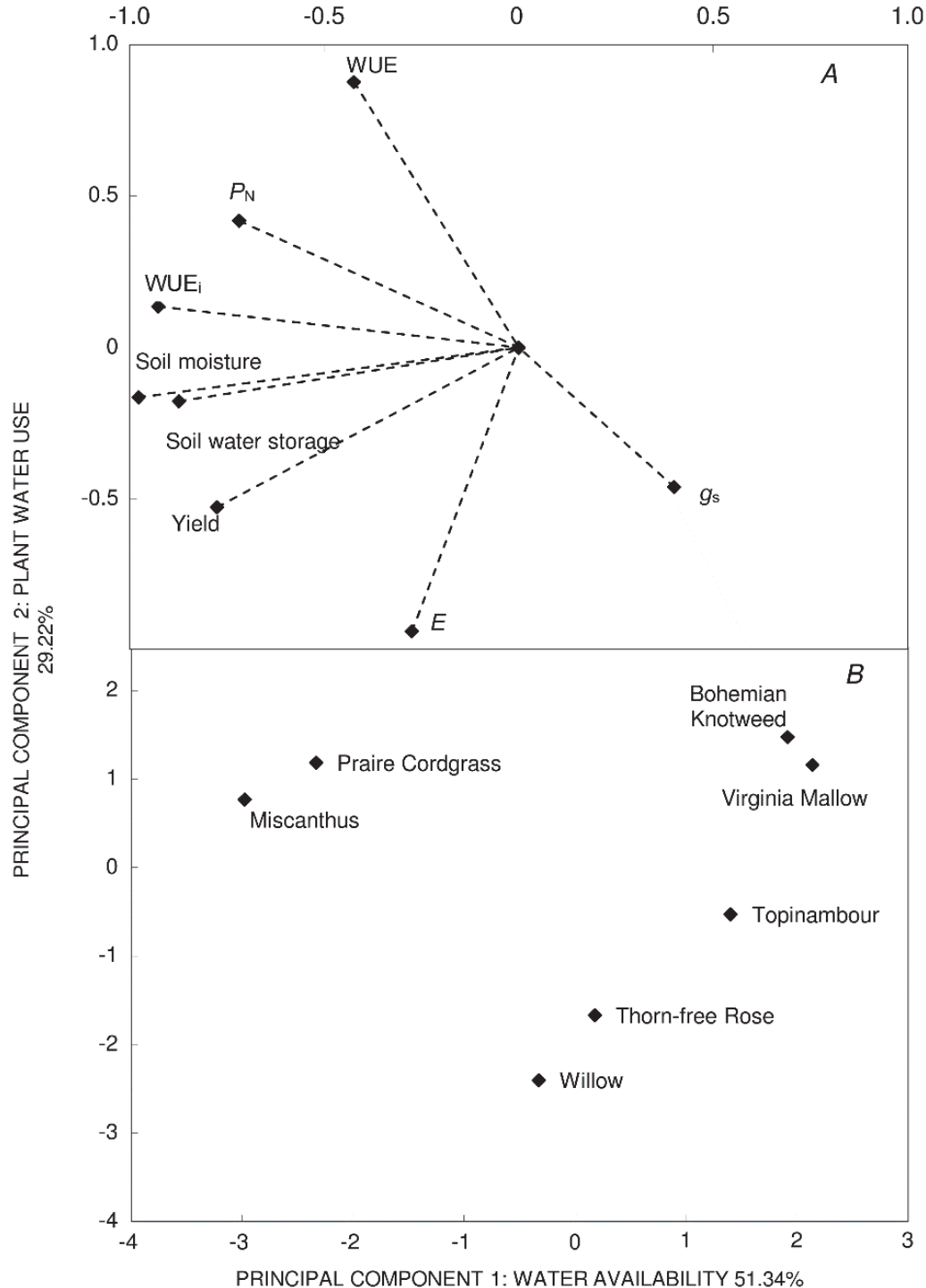

Fig. 4. Scatterplot of principal component analysis (PCA) data showing the size of correlations between measured gas exchange and soil water parameters as well the share of two component responsible for majority of variability in measured traits; $\mathrm{g}_{\mathrm{s}}$ - stomatal conductance; $E$ - transpiration rate, WUE, WUE - instantaneous and intrinsic water use efficiency, respectively; $P_{\mathrm{N}}-$ net photosynthetic rate $(A)$. Scatterplot of principal component analysis (PCA) data showing the placement of seven energy crops according to the coordinates of two components (soil water availability and plant water use) responsible for majority of variability of measured traits $(B)$. indicated that one ploughing around plantation during vegetation substantially limits expansion of Bohemian knotweed plants.

Due to the great diversity in the nature of the energy crops studied, sometimes differentiated, displaying irregular responses to water conditions, neither WUE nor $\mathrm{WUE}_{\mathrm{i}}$ can be treated as universal photosynthetic measures for the evaluation of water-use efficiency under the varied conditions of cultivation for different energy crops. Moreover, from our data, it is clear that both indices are more useful in the assessment of both subtypes $\mathrm{C}_{4}$ tall grasses, characterized by a big increase in the biomass yield, $g_{\mathrm{s}}$, and $E$ following ever increasing rainfalls as the $P_{\mathrm{N}}$ is differentiated to a lesser extent.

In conclusion, energy crop cultivation decreased soil moisture, especially in the deeper layers of the soil profile, and reduced average soil water storage at a $0-100 \mathrm{~cm}$ depth of the soil profile by $23.8-44.1 \mathrm{~mm}$, when compared with the soil under oats (control). Soil water storage was positively correlated with the biomass yield of energy crops. Additionally, in PCA analysis, the soil water availability determined by soil water storage and moisture content was positively correlated to a great extent with the biomass yield. The second component resulting from PCA called plant water use, determined mainly by stomatal conductance and transpiration rate, was to a lesser degree correlated with the biomass yield.

Based on net photosynthesis and transpiration rates (WUE), or on stomatal conductance (WUE $\mathrm{W}_{\mathrm{i}}$, indicators of plant water use should not be used as common measures for the assessment of water-use efficiency by energy crops due to the highly differentiated response of these crops under various vegetation seasons. Moreover, this response might be profitably modified by regional characteristics of the environments. 
Open Access This article is distributed under the terms of the Creative Commons Attribution License which permits any use, distribution, and reproduction in any medium, provided the original author(s) and the source are credited.

\section{References}

Bacon M.A.: Water Use Efficiency in Plant Biology. Pp. 344. Blackwell Publishing Ltd., Oxford 2004.

Balogh L.: Japanese, giant and Bohemian knotweed (Fallopia japonica (Houtt.) Ronse Decr., $F$. sachalinensis (Frdr. Schmidt) Ronse Decr.and $F$. × bohemica (Chrtek et Chrtková) J. P. Bailey). - In: Botta-Dukát Z., Balogh L. (ed.): The most Important Invasive Plants in Hungary. Pp. 13-33. Institute of Ecology and Botany, Hungarian Academy of Sciences, Vácrátó 2008.

Biniak-Pieróg M.: Dynamics of water content in light bare soil in summer half-year in the period of 2003-2012 and its agrometeorological determinants. - J. Water Land Dev. 22: 41-50, 2014.

Blanco-Canqui H.: Energy crops and their implications on soil and environment. - Agron J. 102: 403-419, 2009.

Blum A.: Drought resistance, water-use efficiency, and yield potential - are they compatible, dissonant, or mutually exclusive? - Aust. J. Agr. Res. 56: 1159-1168, 2005.

Blum A.: Effective use of water (EUW) and not water-use efficiency (WUE) is the target of crop yield improvement under drought stress. A review. - Field Crop. Res. 112: 119-123, 2009.

Buchmann N., Brooks J.R., Rapp K.D., Ehleringer J.R.: Carbon isotope composition of $\mathrm{C}_{4}$ grasses is influenced by light and water supply. - Plant Cell Environ. 19: 392-402, 1996.

Clifton-Brown J.C., Lewandowski I., Andersson B. et al.: Performance of 15 Miscanthus genotypes at five sites in Europe. - Agron J. 93: 1013-1019, 2001.

Condon A.G., Richards E.A., Rebetzke G.J., Farquhar G.D.: Improving intrinsic water-use efficiency and crop yield. - Crop Sci. 42: 122-131, 2002.

El Bassam N.: Energy Plant Species: Their Use and Impact on Environment and Development. Pp. 321. James \& James Sci. Publ. Ltd., London 1998.

El Bassam N.: Handbook of Bioenergy Crops: A Complete Reference to Species. Pp. 545. Earthscan Ltd., London Washington, DC, 2010.

Fan Y., Wang Q., Kang L. et al.: Transcriptome-wide characte- rization of candidate genes for improving the water use efficiency of energy crops grown on semiarid land. - J. Exp. Bot. 66: 6415-6429, 2015

Hall R.L.: Grasses for Energy Production Hydrological Guidelines. DTI New and Renewable Programme. Pp. 15. Crown Copyright, Wallingford 2003.

Jollife T.T.: Principal Component Analysis, $2^{\text {nd }}$ ed. Springer Series in Statistics. Pp. 488. Springer Verlag, New York Berlin - Heidelberg 2002.

Kocacinar F., Sage R.F.: Photosynthetic pathway alters xylem structure and hydraulic function in herbaceous plants. - Plant Cell Environ. 26: 2015-2026, 2003.

Lewandowski I., Scurlock J.M.O., Lindvall E., Christou M.: The development and current status of perennial rhizomatous grasses as energy crops in the US and Europe. - Biomass Bioenerg. 25: 335-361, 2003.

Long S.P.: Ecology of C4 photosynthesis. - In: Sage R.F., Monson R.K. (ed.): C4 Plant Biology. Pp. 215-242. Academic Press, San Diego 1999.

Long S.P.: Ecology of $\mathrm{C}_{4}$ photosynthesis. 7. Environmental responses. - In: Sager R.F., Monson R.K. (ed.): $\mathrm{C}_{4}$ Plant Biology. Pp. 215-243. Academic Press, San Diego 2003.

Long S.P., Zhu X.G., Naidu S.L., Ort D.: Can improvement in photosynthesis increase crop yields? - Plant Cell Environ. 29: 315-330, 2006.

Ripley B.S., Frole K., Gilbert M.: Differences in drought sensitivities and photosynthetic limitations between cooccurring $\mathrm{C}_{3}$ and $\mathrm{C}_{4}$ (NADP-ME) Panicoid grasses. - Ann. Bot.-London 105: 493-503, 2010.

Sokal R.R., Rohlf F.J.: Biometry. $3^{\text {rd }}$ ed. Pp. 937. WH Freeman \& Co., New York 1995.

Sosulski T., Szara E., Stępień W., Rutkowska B.: The influence of mineral fertilization and legumes cultivation on the $\mathrm{N}_{2} \mathrm{O}$ soil emissions. - Plant Soil Environ. 61: 529-536, 2015

Tambussi E.A., Bort J., Araus J.L.: Water use efficiency in C3 cereals under Mediterranean conditions: a review of physiological aspects". - Ann. Appl. Biol. 150: 307-321, 2007. 